\title{
Naturally Occurring Radionuclides in Agricultural Products 1
}

Edward A. Hanlon²

\section{Introduction}

This document is a summary of research with the naturally occurring radionuclides in agricultural products associated with phosphatic clays in Florida.

\section{Purpose}

Emphasis in this summary is on providing information needed for a basic understanding of radionuclides and the implications of food and fiber production on the phosphatic clays in central Florida.

An international symposium was convened in 1991 as a part of the Polk County Mined Lands Research and Demonstration Project. Five presentations were given by invited speakers who are nationally known for their work dealing with radionuclides. A symposium Proceedings containing 17 invited and volunteered papers relating to the understanding of low-concentrations of naturally occurring radiation in the human diet was produced in that same year. Nationally reviewed journal papers were subsequently published in 1994. This document summarizes that work and other efforts dealing with low concentrations of radionuclides found in agricultural products originating from reclaimed phosphatic clay.

\section{The Origins of Radionuclides}

Radionuclides addressed in this publication are those from the uranium (U) and thorium (Th) series. The high energies needed to form these radionuclides can only be found in the violent, energy-intensive destruction of a star, a super nova. During the earth's formation, matter was captured from the surrounding space, some of which contained radionuclides. The heavier radionuclides migrated toward earth's newly forming core. Today, researchers believe most of the liquid core of the earth results from energy released from the decay of radionuclides.

\section{Particle and Radiation Losses: Decay Series}

A radionuclide is an atom whose nucleus changes with time. These changes produce several effects:

1. This document is SL221, a fact sheet of the Soil and Water Science Department, Florida Cooperative Extension Service, Institute of Food and Agricultural Sciences, University of Florida. Originally published as SS-MLR-5, June 1993. Revised as SL221, December 2004. Visit the EDIS Web Site at http://edis.ifas.ufl.edu.

2. Edward A. Hanlon, Professor, Southwest Florida Research and Education Center, Immokalee, FL 34142-9515, Institute of Food and Agricultural Sciences, University of Florida, Gainesville, FL 32611.

The Institute of Food and Agricultural Sciences (IFAS) is an Equal Employment Opportunity - Affirmative Action Employer authorized to provide research, educational information and other services only to individuals and institutions that function without regard to race, creed, color, religion, age, disability, sex, sexual orientation, marital status, national origin, political opinions or affiliations. For information on obtaining other extension publications, contact your county Cooperative Extension Service office. Florida Cooperative Extension Service / Institute of Food and Agricultural Sciences / University of Florida / Larry R. Arrington, Interim Dean 
1. the atom loses matter/energy in such a way that a new element is formed;

2. the energy involved in the change may be sufficient to damage living tissue, if it is exposed for a sufficient time.

This strictly defined process of matter/energy loss is known as a decay series (Cowart and Burnett, 1994, 630; Linsalata, 1994, 633).

\section{Radionuclide Half-Life}

The half-life of a radionuclide is that time period during which one half of the initial number of atoms undergoes decay to the daughter product. Three long-lived radionuclides, uranium isotopes $\mathrm{U}-238$ and U-235 and thorium (Th-232), are the origin of most natural radioactivity on the earth. Each of these radionuclides has an extremely long half-life that ranges from 4,468,000,000 years for U-238 to $13,900,000,000$ years for Th-232.

\section{Chemical Changes}

As the radionuclide decay process goes forward, the chemical activity of the radionuclide changes. A precursor element may be immobile in its current environment, for example radium (Ra-226). The resulting daughter atom after particle ejection is Radon (Rn), which can move through the soil as a gas.

Volcanic activity moves these radionuclides to the earth's surface where they enter into the weathering cycle of rocks and minerals. This process has continued since the formation of the earth, distributing naturally occurring radionuclides everywhere on the earth.

Concentrations of radionuclides occur because of their chemical properties, some being soluble or more mobile, others not. Some radionuclides accumulate due to chemical reactions, for example, while others can be found as gases or in water sources. These processes were at work during the formation of the phosphate deposits in central Florida, causing $U$ to accumulate. Due to the extremely long half-life of $U$, all of the decay products of the U-238 series can be found in these deposits.
The elements of interest are radium (Ra-226), lead (Pb-210), and polonium (Po-210). While there are quite a number of decay series elements between radium and the other two, these three elements are indicators of the entire series. Several daughter series of radon are found in the intermediate decay steps. Since radon is a gas, it is often found to be a health risk because it may be trapped in a well-sealed house.

\section{Mining Operations and Phosphatic Clays}

One of the resulting by-products of phosphate mining is a water-suspended material known as phosphatic clay. These clays contain a sizable portion of silicate clays, phosphate particles, and coarser material (quartz, etc.). A portion of the radionuclides originally in the ore body is also found in the clays.

These clays are deposited hydraulically and undergo a process known as dewatering during reclamation. Water that is removed from the clay is recycled. The clays are managed so they will consolidate. Phosphatic clay has often been reclaimed to wetlands and other environmentally sound uses. However, the value of these lands for intensive crop production may be quite high considering their superior water-holding capacity, high natural fertility, and possible low cost of crop production compared with the sandy surface soils of Florida.

\section{Entry into the Food Chain}

Plants in general may accumulate radionuclides depending upon many factors including species, tissue type (e.g., leaf vs. fruit), soil-water-plant relationships, soil type, and the chemical nature of the radionuclide in the soil. A method for describing this accumulation in a plant is called the concentration ratio (CR) (Mortvedt, 1994, 643). The $\mathrm{CR}$ varies throughout several orders of magnitude and has been found to be nonlinear. Findings indicate that the radionuclides found in plant tissues were quite low compared with that in the soil (CR values reported by Mortvedt, 1994, 643 ranged from 0.00148 to 0.00006 ). Extrapolation of CR determined using high concentrations of processed radionuclides (concentration processes for power plants or other 
human uses) to the relatively low concentrations of naturally occurring radionuclides is inaccurate, resulting in much higher $\mathrm{CR}$ values than those reported in agricultural field studies.

Factors or ratios have been calculated for many other points in the food chain where a radionuclide may be excluded or accumulated (Roessler et al., 1991, 196). For example, the gastro-intestinal tract of humans excludes $80 \%$ or more of radionuclides. This ratio, comparing radionuclide concentrations absorbed through the gastrointestinal tract to the total radionuclide concentration in the food, is termed " $f l$." A similar ratio has been used to describe animal accumulation from food stuffs, termed " $f m . "$

In each case, the ratio or factor is usually much less than 1 , a value that would be equivalent to a complete transfer from soil to plant. Findings indicate that each transfer point in the food chain normally acts to reduce the radionuclide concentration in the tissue or organ higher in the food chain. The CR for vegetables/soil transfer of Ra-226 was reported as 0.0080 , while the $\mathrm{fm}$ for cow milk/feed was 0.0004 (Linsalata, 1994, 633). Looking at these ratios a bit closer, the $\mathrm{CR}$ value indicates that less than 1 percent of the Ra-226 found in the soil is actually accumulated in the vegetables tested in these studies. The transfer of Ra-226 from cattle feed to the milk is much more restrictive, only about 0.04 percent (4/100ths of 1 percent) is passed from the feed to the milk.

Within animals and humans, certain tissues tend to accumulate selected radionuclides. This information can help with dietary choices (e.g., avoiding the consumption of animal organs that accumulate radionuclides) as well as in the calculation of dose. For example, certain animal organs do not accumulate radium (Ra-226) or lead (Pb-210) (e.g., kidney and muscle), while other tissue may (e.g., bone). Thus, humans consuming cattle muscle tissue (beef) will be exposed to lowered concentrations of radionuclides than actually ingested by the cattle simply because the radionuclides accumulated in the bone.

\section{Radiation Dose}

The harmful effects of radionuclides do not come from their chemistry within tissue, but from the radiation associated with radioactive decay. Radiation of tissue increases the risk of cancer. However, the risk varies according to the type and energy of radiation, residence time in the selected tissue, and concentration of the radionuclide. Knowing these factors, the dose or exposure to the radionuclide can be calculated. Dose is simply the product of the radionuclide intake and the appropriate dose conversion factor (DCF). Dose is reported in terms of Sieverts, which is equivalent to $1 \mathrm{Joule} / \mathrm{kg}$.

Several recommendations are currently under consideration for determining when an individual or group can be considered "below regulatory concern" (BRC) (Roessler et al., 1991, 206). While it might be argued that no exposure at all is the only acceptable BRC, such an approach is not realistic. Humans and their food chains are exposed to many different sources of radiation, all resulting from environmental sources. Humans are exposed to radiation from cosmic rays [0.27 milliSieverts/yr $(\mathrm{mSv} / \mathrm{yr})$ ], indoor radon $(2.0 \mathrm{mSv} / \mathrm{yr})$; and Ra-226 in the human body $(0.01 \mathrm{mSv} / \mathrm{yr})$ (Walsh, 1991, 185).

The proposed standard for an individual in the population for whole body continuous exposure is 1.0 mSv/yr (Roessler et al., 1991, 206). Continuous exposure means that a person is exposed to this small amount of radiation every day. Note that the average exposure for most people due to radon is already higher than the proposed standard.

\section{Risk due to Naturally Occurring Radionuclides}

One often talks about the risk or hazard associated with an activity. For example, the health risk that an individual will die from cancer from smoking expressed on an annual basis is one in 1000 . Since a significant portion of the population smokes, such a risk is considered "acceptable" by that portion of the population that smokes.

Operating a car carries with it a certain risk of injury, but that risk is considered "acceptable" as evidenced by the number of drivers. The annual risk 
for an individual in the United States of being in a fatal car accident is approximately one in 10,000 (Walsh, 1991, 187).

The annual risk of fatality due to a hurricane, lightning, or tornadoes is one in 100,000. Lastly, the annual risk of cancer caused by naturally occurring radionuclides in food is one in $1,000,000$. Such low risks are orders of magnitude lower than the accepted risks of driving and smoking. The annual cancer risk due to background radiation is equivalent to the risk of an automobile accident, indicating that the overall risk from radionuclides in food is low (Walsh, 1991, 186).

The actual radiation risk can be calculated if the dose equivalent is multiplied by the risk coefficient. The risk coefficient is equal to $0.05 / \mathrm{Sv}$ (Roessler et al., 1991, 208). It is also appropriate to express the long-term risk by multiplying the annual risk by the number of years in consideration. For a fifty-year period, the risk of developing a fatal cancer from any source is one in six, while the risk associated with a diet of enhanced naturally occurring radionuclides is one in 4,000 .

\section{Radionuclides in Products from Phosphatic Clays}

The symposium proceedings contain six papers directly addressing research on phosphatic clays or lands disturbed during phosphate mining operations. The following information represents a summary of these works.

All studies concluded that crops grown on phosphatic clays generally contained higher concentrations of radionuclides than those grown on undisturbed mineral soils. However, the concentrations varied significantly with the type of crop and the part(s) harvested for food. In general, the concentrations of radium ( $\mathrm{Ra}-226)$, lead $(\mathrm{Pb}-210)$, and polonium (Po-210) were lower in grain and fruit than in vegetative portions (leaves, stems, roots). For example, the radium (Ra-226) content in the seeds of corn, sunflower, and grain sorghum was about 8 percent of that found in the leaves and stems (Mislevy et al., 1991, 113).
Vegetables grown on phosphatic clays also contained higher concentrations of radionuclides than those grown on undisturbed mineral soils. The lowest concentrations were found in the fruit and the highest found in the older leaves (Shibles and Riddle, 1991, 260). The outermost leaves of cabbage, which typically are removed before food preparation, contained higher concentrations than cabbage heads (Shibles and Riddle, 1991, 271). Radionuclide concentrations differed little in cabbage heads grown on phosphatic clays compared with those grown on undisturbed soil. Vegetables produced for their edible leaves, such as turnip and collard greens, had higher radionuclide concentrations than root crops, such as carrots or turnip roots (Million et al., 1994, 671; Shibles and Riddle, 1991, 270).

Cattle were used in two studies to evaluate the impact of forages grown on phosphatic clays on concentrations of radionuclides in the animals and their products. No differences were noted for heifers receiving diets of corn silage or alfalfa grown on phosphatic clays compared with heifers fed similar feed produced on undisturbed land. No effects due to diet were found in the offspring. Milk from cows fed corn silage grown on phosphatic clays contained from 0.010 to 0.023 Bequerels radium (Ra-226) per liter. These values were only slightly above the normal range reported for milk produced in the United States of 0.003 to 0.010 Bequerels radium (Ra-226) per liter (Staples et al., 1994, 663).

Steers had greater concentrations of radium (Ra-226) in bone samples than in muscle or kidney tissues regardless of the source of forage. There were no differences in the bone concentrations among forage sources. This finding indicates that while the dietary intake of these animals was somewhat different due to the radium (Ra-226) concentrations in the forage, the $\mathrm{fm}$ (see definition above) of steer/forage was such that most of the radionuclide was excreted and not absorbed. Concentrations of radium ( $\mathrm{Ra}-226)$, lead $(\mathrm{Pb}-210)$, and polonium (Po-210) found in the muscle were almost three orders of magnitude lower than concentrations found in the bone (Stricker et al., 1994, 667).

Guidry et al. (1990 and 1991, 169) summarized a survey of foods grown on mined lands, including 
so-called debris land and phosphatic clays. To

estimate dosage, researchers considered three types of individuals:

1. a control individual whose diet consists of foods grown on undisturbed mineral soils;

2. a local individual who obtained $10 \%$ of their food from phosphatic clays;

3. a theoretical maximum exposure individual whose diet was obtained solely from foods grown on phosphatic clays.

The control individual was estimated to receive a dose of $0.16 \mathrm{mSv} / \mathrm{yr}$, while the local individual incurred an estimated dose of $0.17 \mathrm{mSv} / \mathrm{yr}$.

Converting these numbers to actual annual cancer risk, the risk increased from the control of 8.2 in $1,000,000$ to the local individual's risk of 8.4 in $1,000,000$ per year, a negligible change.

\section{Summary}

1. Radionuclides that occur naturally in our environment pose little threat of dietary cancer.

2. The natural range in radionuclide content among various kinds of foods is greater than the difference in radionuclide content between the same foods produced on phosphatic clays or on natural soils.

3. Products such as fruits, grains, and beef are naturally lower in radionuclides than green, leafy vegetables.

4. Soils with elevated concentrations of radionuclides, such as the phosphatic clays, can be used for the production of agronomic and vegetable crops without an appreciable increase in health risks to either animals or humans. However, fruits or grain, rather than leafy vegetables, are the best crop candidates for minimizing health risks.

5. Milk and beef from cattle-fed forages produced on the phosphatic clays showed radionuclide concentrations that were only slightly above the normal range.
6. A dose/risk assessment approach indicated that the consumption of foods produced on phosphatic clays did not appreciably increase the cancer risk.

7. Restrictions on food production on reclaimed phosphate lands do not appear to be warranted (Guidry et al., 1991, 168).

8. The risk associated with radionuclides in foods (about 1 in 1,000,000/yr) are considered to be insignificant or de minimis (Walsh, 1991, 190).

\section{Information sources and summary articles on this subject}

Cowart, J.B., and W.C. Burnett. 1994. The distribution of uranium and thorium decay-series radionuclides in the environment-A review. J. Environ. Qual. 23:651-662.

Guidry, J.J. 1990. Radioactivity in foods grown on mined phosphate lands. FIPR Pub. No. 05-028-088, Bartow, FL.

Guidry, J.J., C.E. Roessler, W.E. Bolch, J.T. McClave, C.C. Hewett, and T.E. Abel. 1991. Radioactivity in foods grown on mined phosphate lands. p. 164-171. In Hanlon, E.A. (ed.) 1991. Symposium proceedings of naturally occurring radionuclides in agricultural products. Proc. Symposium UF/IFAS, FIPR, ASSMR, Fla. Chap. HPS, MLARD, Savannah River Ecol. Lab., and South. Regional Reclamation Committee (S-245) SSSA, Orlando, FL. 24-25 Jan.

Hanlon, E.A. 1994. Naturally occurring radionuclides in agricultural products-An overview. J. Environ. Qual. 23:630-632.

Hanlon, E.A., R.A. Jerez, J.A. Stricker, D.B. Shibles, and T.C. Riddle. 1996. Naturally occurring radionuclides in agricultural products. p. 16-26. In Hanlon, E.A., R.A. Jerez, and J.A. Stricker (eds.) 1996. The mined lands agricultural research and demonstration project: Summary of experiments and extension recommendations. Florida Institute of Phosphate Research. Bartow, FL. Pub. No. 03-093-128. 115 pp. 
Linsalata, P. 1994. Uranium and thorium decay series radionuclides in human and animal food chains-A review. J. Environ. Qual. 23:633-642.

Million, J.B., J.B. Sartain, R.X. Gonzalez, and W.D. Carrier III. 1994. Radium-226 and calcium uptake by crops grown in mixtures of sand and clay tailings from phosphate mining. J. Environ. Qual. 23:671-676.

Mislevy, P., C.E. Roessler, and W.G. Blue. 1991. Radium-226 uptake and dry matter yield for selected field, forage, and biomass crops grown on a phosphatic clay settling area. p. 90-114. In Hanlon, E.A. (ed.) 1991. Symposium proceedings of naturally occurring radionuclides in agricultural products. Proc. Symposium UF/IFAS, FIPR, ASSMR, Fla. Chap. HPS, MLARD, Savannah River Ecol. Lab., and South. Regional Reclamation Committee (S-245) SSSA, Orlando, FL. 24-25 Jan.

Mortvedt, J.J. 1994. Plant and soil relationships of uranium and thorium decay series radionuclides-A review. J. Environ. Qual. 23:643-650.

Roessler, C.E., W.E. Bolch, B. Birky, and G.S. Roessler. 1991. Dose estimation and risk assessment for naturally occurring radionuclides in agricultural products. p. 194-212. In Hanlon, E.A. (ed.) 1991. Symposium proceedings of naturally occurring radionuclides in agricultural products. Proc. Symposium UF/IFAS, FIPR, ASSMR, Fla. Chap. HPS, MLARD, Savannah River Ecol. Lab., and South. Regional Reclamation Committee (S-245) SSSA, Orlando, FL. 24-25 Jan.

Shibles, D.B., and T.C. Riddle. 1991. Levels of Radium-226 in crops grown on phosphatic clay at the Polk County Mined Lands Agricultural Research/Demonstration Project. p. 260-275. In Hanlon, E.A. (ed.) 1991. Symposium proceedings of naturally occurring radionuclides in agricultural products. Proc. Symposium UF/IFAS, FIPR, ASSMR, Fla. Chap. HPS, MLARD, Savannah River Ecol. Lab., and South. Regional Reclamation Committee (S-245)

SSSA, Orlando, FL. 24-25 Jan.
Staples, C.R., R. Umana, J.A. Stricker, D. Shibles, M.J. Hayen, C.D. Hissem, D.S. Lough, and D.L. Demorest. 1994. Radionuclides in milk of dairy heifers raised on forages harvested from phosphatic clay soils on reclaimed mined land. J. Environ. Qual. 23:663-667.

Staples, C.R., R. Umana, J.A. Stricker, D. Shibles, M.J. Hayen, C.D. Hissem, D.S. Lough, and D.L. Demorest. 1994. Excretion of radionuclides in milk of dairy heifers fed forages harvested from phosphate mined reclaimed soils. p. 71-82. In Shibles, D.B. (ed.) 1994. Polk County mined lands agricultural research/demonstration project report: Three-year summary. Prepared for the Florida Institute of Phosphate Research. Bartow, FL. FIPR Publ. No. 03-088-107.

Stricker, J.A., E.A. Hanlon, S.L. Sumner, D.B. Shibles, and R.L. West. 1994. Naturally occurring radionuclides in tissue from beef fed forages grown on phosphatic clay. J. Environ. Qual. 23:667-670.

Stricker, J.A., E.A. Hanlon, R.L. West, D.B. Shibles, S.L. Sumner, and R. Umana. 1994. Naturally occurring radionuclides in tissue from beef fed forages grown on phosphatic clay. p. 61-70. In Shibles, D.B. (ed.) 1994. Polk County mined lands agricultural research/demonstration project report: Three-year summary. Prepared for the Florida Institute of Phosphate Research. Bartow, FL. FIPR Publ. No. 03-088-107.

Walsh, P.J. 1991. Radioactivity in foods: Putting the risk in perspective. p. 174-193. In Hanlon, E.A. (ed.) 1991. Symposium proceedings of naturally occurring radionuclides in agricultural products. Proc. Symposium UF/IFAS, FIPR, ASSMR, Fla. Chap. HPS, MLARD, Savannah River Ecol. Lab., and South. Regional Reclamation Committee (S-245) SSSA, Orlando, FL. 24-25 Jan. 